\section{Acquisitions of the British Museum (Natural History)}

THE Department of Geology has recently acquired, through the generosity of the Medical Committee of the Royal Dental Hospital, a molar tooth of Nean. derthal man discovered in Genista Cave, Gibraltar, in 1865 by Capt. F. Brome, governor of the Military Prison. The most interesting recent acquisition in the Department of Minerals is a gilt brass model of a gold nugget from the foot of Croghan, Kinshela, near Arklow in County Wicklow. The original nugget was found in 1795 . It was said to have weighed 22 ounces and to have been given to King George III by Abraham Coates in 1796. A model is preserved in Trinity College, Dublin, and a plaster model was presented to the British Museum in 1910. The new model is presented by Lord Seaton. Two fine specimens of hydromuscovite with pyrite and arsenopyrite from the Roman Deep Mine, Ogofar, Carmarthenshire, and specimens of a New British mineral, russellite, a mixed crystal of bismuth and tungstic oxides, from Cornwall, are the most interesting of the other British additions. Natural glasses of problematical origin generally classed as tektites continue to appear in various parts of the world. Through Dr. Spencer, forty-eight specimens of natural glass from Java have been presented by Dr. G. H. R. von Koenigswald. Prof. Suess of Vienna has presented a piece of the so-called köfelsite-a fused gneiss from the supposed meteorite crater at Köfels in the Austrian Tyrol. The Department has acquired by purchase some fine groups of cassiterite from Bolivia from Messrs. Gregory and Bottley and has also secured the greater part of the collection of Hugh Septimus Gordon, who specialized in collecting and studying the minerals of the rare earths.

\section{Excessive Marine Growth in Shoreham Harbour}

A SHORT time ago a letter appeared in the Press stating that coral was growing in the Southwick basin of Shoreham Harbour, Sussex, and was causing considerable trouble by fouling the bottoms of yachts and small boats lying in this part of the harbour. The Southwick canal, or basin, is locked off from the rest of Shoreham Harbour, its waters being kept at a constant level and free from tidal rise and fall. The sea water in the basin is used to cool the condensers of the Brighton and Hove electric power station, which is situated on its seaward side with coal wharves on the basin. Being of limited area, the water in the basin is appreciably warmed by this means, and is said not to fall below a minimum of about $65^{\circ} \mathbf{F}$. At first this growth was thought to be a tropical reef-building coral which had somehow managed to survive the passage from Pacific or West Indian seas on the bottom of a yacht about a year ago, and was able to thrive in the comparatively warm waters of the basin.

The British Museum (Natural History) was asked to investigate, and Mr. Dilwyn John is at present collecting specimens of the local marine fauna and flora living under the peculiar conditions occurring in the Southwick basin. The 'coral' turned out to be an excessive growth of a polychæte worm, closely resembling Hydroides norvegica Gunnerus (Serpulidæ), which lives in tubes of a calcareous nature. It is possibly a species new to science, and is being described by Mr. C. C. A. Monro of the British Museum (Natural History). The growth consists of dense brittle clusters of the white tubes of this worm, which grow to approximately $9 \mathrm{~cm}$. long and average $1 \mathrm{~mm}$. in diameter, and are usually cemented one to another. It occurs more frequently around the water-line of floating objects than on piles or the keels of boats, which appears to indicate that light and aeration are favourable to its growth; but the warm water of the Southwick basin seems to be the chief cause of its present excessive development. Perhaps after a full investigation other less conspicuous marine organisms may be found to be behaving in a peculiar manner on account of the interesting conditions occurring in this part of Shoreham Harbour.

\section{Registration and Population Trends}

A PAPER read by Dr. R. R. Kuczynski before the Eugenics Society on future trends in population is published in the Eugenics Review, 29, No. 2. He points out that in 1837 an Act was passed for register. ing births, deaths and marriages in England, more than sixty years after such demographic data were recorded in Sweden. His address is mainly devoted to showing the inadequacy of the records as kept in Great Britain compared with those of various other countries, our original birth and death registration forms having remained unaltered up to the present time. The age of the mother at the birth of each child was recorded in Sweden so early as 1774, and in 1839 the Compiler of Abstracts in the General Register Office wrote a letter to the Registrar-General pointing out two grave defects in the records, but nothing has been done. The need is stressed particularly for recording the age of the parents, especially the mother, at the birth of each child, the order of birth and the duration of the marriage, as well as the date of birth. Without such data it is impossible to determine questions of differential fertility and population growth or decline. Various suggestions are made, including that of a special fertility census in December 1938. We should then have within three years a fair knowledge of present fertility trends, on which a Government population policy could be formulated with some chance of success.

\section{Conference on Atmospheric Pollution}

ThIRTY-six representatives of local authorities and other organizations co-operating with the Department of Scientific and Industrial Research met on November 29 in the half-yearly conference. Dr. G. M. B. Dobson, chairman of the Atmospheric Pollution Research Committee, presented the report on the progress of the investigations carried out under the Committee. He spoke in particular of the results which are being obtained in the special survey which is in progress in and around the City of Leicester. Two sources of atmospheric pollution which occur in 